\title{
Até que ponto a experiência artística, em particular a de Teatro de Marionetes, permite o surgimento de habilidades pessoais?'
} Dans quelle mesure l'expérience artistique, en particulier celle du Théâtre de Marionnettes, permetelle l'émergence des compétences personnelles?

Philippe Choulet ${ }^{2}$ 


\section{Resumo}

O objetivo desta palestra é complexo, pois pertence à psicologia filosófica e, precisamente, à psicologia do artista, ou daquele que quer se apresentar como tal, e seu intuito é o de introduzir primeiro a questão da emersão como mudança radical, como "passagem para a qualidade", depois da ética pessoal da produção daquele que chamamos "autor".

Palavras-chave: Teatro de Marionetes; habilidades pessoais; autor

\section{Abstract}

L'objet de cette conférence est complexe, parce qu'il relève de la psychologie philosophique et précisément de la psychologie de l'artiste, ou de celui qui veut se présenter comme tel, afin d'introduire d'abord la question de l'émergence comme changement radical, comme " passage à la qualité », ensuite celle de l'éthique personnelle de la production chez celui que nous appelons un « auteur ».

Keywords: Théâtre de Marionnettes; compétences personnelles; auteur

${ }^{1}$ Recordo o tema inicial da minha intervenção, para a qual fui convidado a trabalhar: o impacto da experiência teatral e de produções artísticas na descoberta de habilidades pessoais e de seu aprimoramento no nível técnico, ético e humano.

2 Professor de Filosofia no Lycée Fustel de Coulanges e Lycée Kléber em Estrasburgo. Diretor do Revue L'Animal. França. 
O objetivo desta palestra é complexo, pois pertence à psicologia filosófica e, precisamente, à psicologia do artista, ou daquele que quer se apresentar como tal, e seu intuito é o de introduzir primeiro a questão da emersão como mudança radical, como "passagem para a qualidade", depois da ética pessoal da produção daquele que chamamos "autor".

Especifico o que falo aqui como espectador, teórico do Teatro e do Teatro de Marionetes, como escritor sobre Música, professor e escritor de Filosofia, Filosofia da Arte e História da Arte. Pode parecer "aristocrático" ou "elitista", mas a questão também é democrática, como veremos, porque se estende a todos, já que todos nós temos uma experiência artística (produção, manufatura, concepção, encenação, criação, etc.), ou uma experiência estética, a do espectador (o espectador de suas próprias obras, o espectador das obras de outros).

1.1. Nosso problema é, antes de tudo, a estética da criação, a maneira pela qual o autor se autoriza: pelo que se faz, em si e por si mesmo, a legitimação de seu trabalho, na medida em que também é feito por seus colegas de trabalho, pelas instituições, pelo público e pelo discurso da história da arte. Pois é uma questão de reconhecer habilidades e não apenas submeter-se a um julgamento de autoridade arbitrária vindo da tradição ou da história, da aura, do prestígio e carisma de um ou outro, ou da glória e celebridade midiática. Há muitos artistas (mas eles não são os únicos) que só permitem a eles mesmos e a alguns outros poucos (para formar um clã em um "plano de mídia") querer passar por gênios notórios, enquanto inventam suas próprias provas. Pergunta antiga: quem te fez rei? Parece-nos, por razões bastante compreensíveis que discutiremos mais adiante, que o Teatro de Marionetes tende a tornar-se mais modesto e a refrear o narcisismo excessivo do artista de hoje ${ }^{3}$, para não ser banido.

Por que querer se tornar um autor ou querer se passar por um autor? Por que "ser (um) autor" é tão valioso: valor de uso ou valor de troca em um mercado de arte? É que as noções de autor e autoridade se referem primeiro a um poder ou autoridade, especialmente dentro das instituições. Mas, felizmente, eles não significam apenas o exercício do poder: eles pertencem, etimologicamente - e este é um dos verdadeiros fins da arte, e também das relações humanas - ao registro do aumento do mundo (auctoritas e aumento têm a mesma raiz etimológica), o aumento do poder de ser e afetar (produzir efeitos), a intensificação da vida (Nietzsche) e o aumento do campo de consciência, de lucidez e senso crítico (isto é, emancipação, por iluminação, aufklärung, em alemão). Pode-se até sonhar, como Proust, com o trabalho de um artista revelando a verdade da vida.

\footnotetext{
${ }^{3}$ Lembre-se do aviso de Baudelaire, observando tanto o crescente poder dos artistas para a burguesia, quanto o orgulho de serem ignorantes, já em 1859: "O artista moderno é um menino mimado". Baudelaire já sente, à sua maneira, a questão da diferença entre o que triunfa de fato e o que deveria prevalecer na lei ou na razão.
} 
1.2. O problema do surgimento de habilidades pessoais é de natureza "psicológica". O que significa "psicológico", aqui? O termo tem três significados:

a. Psicológico significa a lógica da alma (logos/psyché), a lógica de sua palavra, sua expressão, sua racionalidade (logos significa palavra e razão); essa "alma" é tão individual quanto coletiva, por causa da dívida que todos, mesmo isolados, selvagens e independentes, mantêm por necessidade com as "almas coletivas" ("almas coletivas" é uma expressão do sociólogo Jean Duvignaud).

É porque cada um de nós é vários ou, como diz Nietzsche4, nossa alma é plural. Sabemos, no fundo de nós mesmos, que não somos feitos apenas de nós mesmos, que somos ambos herdeiros (René Char diz: "nossa herança é sem testamento") e contrabandistas; anões empoleirados nos ombros de gigantes; que nossa substância pessoal é composta de causas, influências, determinações muito diversas, muitas vezes esquecidas, negadas e reprimidas. Nossa idiossincrasia é um resultado distante de relações de produção muito complexas e inconscientes para muitos.

Somos ótimos amnésicos. Certamente, alguma forma de esquecimento é necessária e até às vezes desejável - como Borges insiste em Funes ou a Memória (publicado em Ficções), quando ele diz que é impossivel para Funes estar presente no presente, porque ele sofre de nunca deixar de lembrar-se de tudo. $O$ tecido conjuntivo de nossa mente, alma e corpo combinados, é uma "eclusa de ar", uma bacia de decantação, onde uma seleção seletiva acontece, com algumas lições aprendidas bem e bem retidas, e às vezes lições reprimidas, mas ainda assim e sempre ativo, não duvide disso nem por um segundo.

Nossas sensibilidades, nossos gostos, nossas inclinações, nossos afetos, nossas paixões, têm uma história que nos liga à humanidade. Nossa alma individual está aqui experimentando a ambivalência de sua história, que pode ser uma riqueza, uma plenitude, uma boa saúde ou uma deficiência, um peso, uma miséria, uma doença (como na memória obsessiva).

b) "psicológico", então, mostra o modo paradoxal pelo qual a experiência artística vai além da consciência, como dizem Kleist, Nietzsche ou Freud (há um paradoxo porque a verdade da consciência não é em si mesma, se é acima de tudo o lugar de ilusões e ignorância). Este é o significado "metapsicológico", no sentido de Freud. E esta transcendência da consciência não é uma transcendência espiritual, uma transcendência "de cima" (mística e transcendente), mas uma ultrapassagem "de baixo", "por baixo", isto é, pelo corpo, o desejo e a pulsão - a pulsão sendo o elemento da energia psíquica.

Isso torna possivel compreender imediatamente os três exemplos de Kleist no Teatro de Bonecos: primeiro, a inferioridade do dançarino estelar Vestris em rela-

\footnotetext{
${ }^{4} \mathrm{E}$ isto contra a unidade substancial e ontológica da alma pessoal, vinda do platonismo e do cristianismo.

5 Entre estes exemplos, é possível classificar o conceito de Supermarionete, criado por Edward Gordon Craig, como também os números criados por Oskar Schlemmer na Bauhaus. Cf. O. Schlemmer: Théâtre et Abstraction, ed. L'Age d'homme; Lettres et Journaux, ed. Carta Blanca; e L'homme et la figure d'art, Oskar Schlemmer, Collectif, Centre National de La Danse.
} 
ção ao boneco mecânico ${ }^{5}$, a impossibilidade de repetir exatamente a perfeição e a graça de um gesto, a superioridade do instinto animal do urso esgrimista sobre o melhor esgrimista humano; segundo, a idéia de Nietzsche: "Eu nego que o que é feito pela consciência é perfeito", porque "o espírito puro é pura estupidez" (Anticristo, đ 14 - Nietzsche pensa na arte como espírito "impuro" , como "razão impura", que se relaciona com "a grande razão do corpo"), e terceiro, o segundo tópico freudiano que define o Ego como formação de compromisso entre duas instâncias terríveis e contrárias, os impulsos da libido (o ld) e os proibidos (o Superego).

c) "psicológico", enfim, significa no sentido metassomatológico, metapsico-somatológico, se estamos atentos à importância do trabalho obscuro e oculto do corpo na experiência artística (passando dos cinco sentidos ao afeto imaginário do interior subjetivo, através das impressões e dos modelos/esquemas motores da ação - para Kant, a imaginação transcendental é a única, profunda e secreta fonte das formas mentais em nós). A idéia da metassomatologia refere-se a Nietzsche - o poder da embriaguez criativa como um afeto superior ${ }^{6}$ - e a da metapsicosomatologia se refere aos herdeiros de Freud: Didier Anzieu, Winnicott, Groddeck, Hans Prinzhorn. Hans Prinzhorn é quem "inventou" a arte dos doentes mentais. Assim como o termo "psicológico".

2.1. Vamos tentar agora colocar um pouco de ordem em todo esse labirinto de conceitos. Vamos falar da experiência artística, agora. "Artístico" significa: primeiro, a realidade aristocrática, mais vertical e hierárquica da arte (as artes plásticas, as artes liberais). Segundo, a realidade democrática, mais horizontal, mais equivalente, mas também mais prosaica, das artes mecânicas: o ofício (objeto da arte), a técnica (o objeto técnico, a obra de arte), a bricolagem (pense no personagem de Gaston Lagaffe inventado por Franquin), a arte bruta (Jean Dubuffet, Aloise, Anselme Boix-Vives, Chomo, O Fator Cavalo, Adolf Wölffli, etc.), a arte povera, a arte dos doentes mentais (Hans Prinzhorn), a arte das crianças (Paul Klee). O Teatro de Marionetes deve muito a esta realidade.

Note-se que a nossa modernidade, desde há um bom século, pretende ultrapassar a hierarquia entre artes liberais e artes mecânicas, reconhecendo uma verdadeira dignidade, uma igual dignidade com qualquer operação humana do "fazer o trabalho", que é da era neolítica (a arte dos "primitivos") ou da era industrial (as esculturas, máquinas e móveis de Jean Tinguely, ou videoarte, por exemplo). A revelação das habilidades individuais na e pela prática poética (aquela que produz as obras), é parte da dinâmica do que Lévi-Strauss chama de "pensamento selvagem", que constitui o terreno comum (a palavra "fundo" é, ao mesmo tempo, fundamento, fundação, princípio e fundo, fonte, origem, tesouro das formas) da humanidade universal, como um animal simbólico produzindo seu próprio meio psíquico.

${ }^{6}$ O texto original de Nietzsche é: Crepúsculo dos Ídolos, "Passeios de um Inatual", § 8-9. Ver também Além do bem e do mal, § 230. 
2.2. Nossa experiência artística, que é a do produtor-criador, está fortemente ligada à nossa experiência estética, que é a do espectador (produtor ou não). Também é válido para todo homem comum, seja o homem comum em ação, como diz Dubuffet, o paciente mental isolado em e por sua esquizofrenia, ou o escultor de máscaras e totens de uma tribo, investido pelo imaginário e pelo simbolismo coletivo. A experiência artística e a experiência estética são certamente diferentes, mas estão ligadas como os dois lados de uma moeda, porque qualquer artista-artesão tem necessariamente uma experiência estética, tanto das obras de outros artistas-artesãos quanto dele próprio é um trabalho coletivo inconsciente.

Nosso autor, aquele de quem estávamos falando inicialmente, é passivo a princípio. Recebe impressões, emoções, imagens, formas, mesmo inconscientemente (Leibniz insistiu no jogo das "pequenas percepções", que "nos inclinam sem nos obrigar", o que nos faz inclinar para tal ou qual gosto sem nos determinarmos). Mas essa passividade deve ser qualificada, porque não é absoluta como matéria inerte - e, novamente, poderíamos defender a ideia de que toda matéria não é inerte, pois opõe ao agente uma lógica, uma estrutura, uma resistência determinada.

Nossa passividade vai da passividade mais passiva à passividade mais ativa: da complacência, da inércia, da preguiça enfim, da passividade de aceitação mais ou menos resignada, da apreensão de uma verdade plástica, para a compreensão de um momento de perfeição, para a afirmação de um sucesso e uma conclusão. É um longo processo de transformação, metamorfose, concepção e gênese, que nos retorna em definitivo ao enigma do acabamento do trabalho. A propósito, quando sabemos que nosso trabalho está acabado, finalisado, perfeito, isto é, "perfeito em sua espécie"7?

2.3. Vamos especificar então a experiência. Na minha opinião, "no começo é excitação". As opiniões sobre este começo diferem: o profeta do Gênesis diz que no princípio há a "criação" divina (modelo inacessível, porque ex nihilo, da "criação" humana); para Goethe, é a "ação" (na natureza) e, para Celine, é a "emoção" (como posta em movimento por e pelo afeto). Por que eu digo excitação? É porque a partir da recepção nervosa de uma qualidade, a reação acontece: ou a rejeição (não tomamos) ou a assimilação (tomamos). É como comida: é um alimento ou um veneno. A vida primária da alma física e sensível é feita primeiro desta adversidade entre fobias e apetite.

E nossa vida psíquica superior (fala, pensamento, julgamento) nunca é mais do que a continuação dessa lógica por outros meios. Voltaremos depois a este devir da excitação em nós. Por enquanto, insistamos no fato de que, na experiência artística/ estética, experimentamos a afirmação e a negação, mesmo na suspensão da afirmação e da negação (suspensão no trabalho, na ignorância, na dúvida, na suspeita, por exemplo). Como dizemos tão bem: "escolher é desistir" (Goethe, Hegel). Escolher (afirmar) supõe uma renúncia (uma negação, uma recusa).

E então, o que significa "viver"? Viver é encontrar-se na necessidade de escolher defender uma forma; melhor ainda: é por e impor uma forma, seja ela uma forma externa à matéria, seja a nossa própria no mundo (e nas mentes dos outros); viver é afirmar essas formas, mantê-las no ser, inventá-las, criá-las, recriá-las (gosto dessa 7 Há um texto muito bonito de Audiberti sobre ele: A nova origem, publicado na Poesia-Gallimard. A resposta à nossa pergunta está em Kandinsky, no seu texto
o Princípio da necessidade interna. 
idéia de arte como recriação, criação). Assim, na experiência artística, afirmamos e negamos ao mesmo tempo certas formas, certos sujeitos, certos estilos, certas práticas, em detrimento de todas as outras, de acordo com os momentos da eleição. Van Gogh, afinal, foi sucessivamente realista, naturalista, impressionista, "japanista", para terminar, "expressionista". Cada um de nós é vários.

3.1. Vamos analisar então esta ação que vem bem depois da excitação, bem depois que a excitação se transforma em muitas outras coisas em nós (impressões, imagens, fantasias, cenografias, representações, noções, conceitos, idéias). Essa ação é chamada de prática ou práxis. Existem três formas de práxis, que são articuladas em nós: primeiro, a práxis pura (a expressão, o gesto, o olhar, a atenção, a oração, o êxtase, o endereço - no sentido de endereçar: abordar alguém, endereçar algo para alguém). Segundo, a práxis poética (a produção de uma coisa, um objeto, um ser, separado de seu autor): fabricação, trabalho manual, criação, procriação em uma dialética entre matéria (e sua forma) e a "forma" (a idéia, o modelo, o esquema). Terceiro, a práxis teórica (pensamento, meditação, reflexão, crítica, dúvida, trabalho intelectual).

Como, então, cada um de nós se relaciona com essas formas de práxis? A questão primeiro envolve nossa temporalidade: como encontra-se no livro do Eclesiastes: "há um tempo para uma coisa e um tempo para outra coisa". Com o tempo, podemos ir de uma forma de práxis para outra forma de práxis. Mas, se procurarmos o que está enraizado em nós e como está enraizado, como pode haver simultaneidade em nós de várias formas de ação, devemos colocar o problema estruturalmente e não apenas temporalmente. Proust, também um grande pensador do tempo de nossa interioridade, diz nesse sentido que nosso eu é "laminado", que é feito de "repintes sucessivos" e que cada uma desses repintes é uma camada de memória; que nós mesmos somos feitos de várias estruturas e velocidades de nossa ação, de nossa práxis.

O sujeito humano nao é apenas a série de seus atos (nem a soma nem a síntese); minha alma é apenas a série de minhas idéias (sejam elas tolas, supersticiosas, fanáticas ou verdadeiras, justas, racionais e geniais), meu corpo é apenas a série dos meus afetos (emoções, sentimentos ou paixões) ${ }^{8}$. Só neste fundo vivo de excitações e recursos podem emergir nossas habilidades.

Devemos notar isto: precisamente porque há excitação, nossa alma nunca é um encefalograma plano. A única coisa que não podemos tirar da vida é a excitação, mesmo sob o menor grau de sensação, do mais alto grau de imobilidade ${ }^{9}$. Sempre que há o surgimento de algo novo em nós, supõe a irrupção, o surgimento de uma forma, até mesmo inconsciente. Isso porque a excitação indica essa luta, esse confronto, essa adversidade sem a qual não se "existe", porque a existência é "sair de si", é um movimento que passa por momentos de alteração e alienação nos quais

\footnotetext{
${ }^{8}$ A ênfase aqui é na fragilidade do sentimento de si mesmo, que não pode ser um "eu forte", um "eu substância", um eu defensivo, mas sim um senso de identidade instável, variável e não resolvido. É uma ideia muito literária, que também é encontrada na filosofia: o empirismo anglo-saxão (Hume), Diderot, Nietzsche ou Freud. ${ }^{9}$ Penso no incrível esforço de certos animais que, para fugir de um predador ou, ao contrário, para atrair presas curiosas, fingem a imobilidade da morte, que é uma forma de "fazer crer" pelo jogo das aparências, o que os etologistas chamam de "mimetismo", que é uma forma de mimesis, ao mesmo tempo imitação e simulação (ver Roger Caillois, Les jeux et les hommes).
} 
somos incitados a, convidados a. E é justamente isso que torna a existência não ser simplesmente a vida.

Esta adversidade é uma condição essencial para a revelação e emersão de nossas habilidades. Ela expressa uma dialética entre várias formas de realidade das quais somos feitos e que são distribuídas da seguinte forma: primeiro, a realidade física - a dos corpos e das coisas - às vezes natural (elementos materiais, coisas, vida natural/ selvagem), às vezes cultural, humana e histórica (objetos técnicos, instrumentos, máquinas, artefatos, fantasias, fantoches, obras de arte). Entre parênteses, o Teatro de Bonecos e o Teatro de Objetos, tocam na metamorfose dos elementos naturais em elementos culturais, significantes e simbólicos - mas essa metamorfose é obra da realidade psíquica humana.

Segundo, a realidade psíquica, que é dividida em dois: por um lado, a realidade psíquica individual (você, eu, Beethoven, Sade, Rodin, Kantor, Jack, o Estripador, Jesus), e, por outro lado, a realidade psíquica coletiva espontânea ou selvagem (com a "energia livre": as multidões de linchamentos, os hooligans) e a realidade psíquica coletiva institucional (com a "energia limitada", que "se sustenta": o público de uma classe, uma conferência, um concerto, um desfile militar). E este é o ponto crucial de todas as nossas dificuldades, especialmente aquelas dificuldades que nos impedem de aprender e mudar de acordo com o que aprendemos. Porque a característica de toda "realidade" é que ela resiste - resiste, por um lado, à mudança e, por outro, ao conhecimento, que torna todas as coisas delicadas: a educação, a instrução, a formação, a ciência, a arte, a política por exemplo. Não há surpresas no fato de que é muito difícil mudar o mundo, homens, mentalidades, crenças. Essa adversidade inicia-se no confronto com o inimigo interior: inércia, preguiça, descuido, estupidez, ignorância, servidão. Em suma, tudo o que é "humano, demasiado humano" (Nietzsche), e isso nos coloca na indignidade. Aqui percebemos a questão ética.

Insistiremos: nossas existências são dialéticas, a natureza é guerra, luta e conflito, pólemos e agón. Brecht dizia: o teatro é como o boxe. É necessário lutar contra a matéria, os corpos, as formas, as vozes, as máscaras e de acordo com as regras (móveis, as regras, inevitavelmente móveis). Francis Ponge pensou, por exemplo, que ser poeta significa "falar contra as palavras". A arte - e poderíamos esclarecer que, para o teatro e para o Teatro de Bonecos em particular - é a sublimação desta luta, na forma de jogo, como disse Roger Caillois (Jogos e Homens): conflito (agón), vertigens (ilinx), imitação (mimesis-imitação, mimetismo-simulação) ou o acaso (aleatoriedade). A cada um o seu gosto, aptidões, inclinações, paixões, todos a escolher (e, assim, renunciar ) livremente, ou passivamente, seu dominio de expressão. Este é o fundo exitante e energético sobre o qual se opera tal mudança terrível que é a auto-revelação de si e dos outros, e que supõe o surgimento/a emersão de um novo poder, inesperado, imprevisível.

\footnotetext{
${ }^{10}$ A noção de "transição para a qualidade" indica o desempenho, a realização de outra "natureza", outro "regime", outra velocidade. Mas isso não implica a realização de um fim natural, a conclusão de um poder que seria inscrito em nós como um programa: o gênio artístico é inato, não está escrito em nosso DNA ou em nosso genoma. Essa percepção é antes uma invenção, uma criação anônima (não é nossa responsabilidade, mesmo se formos o teatro, o lugar, o sujeito). É por isso que devemos insistir na passividade e na dimensão involuntária/inconsciente da metamorfose de nossa identidade.
} 
3.2. A revelação de novas habilidades - isto é, novas aprendizagens, novas práticas, novos conhecimentos, novo domínio - é, portanto, um processo doloroso e contraditório, doloroso porque contraditório, já que, como em uma muda, a nova pele ejeta e substitui a anterior, uma vez que se muda de energia. Essa metamorfose é uma "passagem para a qualidade", uma ação ${ }^{10}$ : Proust, no Le Temps Retrouvé $(0$ Tempo Recuperado), diz que a arte é a vida real, porque é o revelador, o desenvolvimento do negativo da existência (revelador, desenvolvimento e negativo são noções emprestadas da fotografia - da era do cinema, é claro!). É certo que isso não é sem dor, como no parto - como já dizia a maiêutica de Platão - exceto que, na ausência de uma parteira ou Sócrates, é o sistema do real e das obras, bem como o work in progress da gênese, que faz o trabalho). Esse parto é uma aventura, o nascimento do trabalho e de si mesmo. Nós somos o que fazemos, e talvez nós somos apenas o que fazemos... de nós mesmos ("de nós mesmos": como fonte e como resultado).

Píndaro tinha visto o paradoxo diante de nós: "Torne-se o que você é". Mas como se tornar se não sabe quem se é? A experiência artística conduz o sujeito a um lugar e uma forma desconhecida, e, inversamente, o trabalho mecânico do artesão, o trabalhador ou proletário, onde reina a dedução do geral para o específico (o modelo, a matriz, o plano alcançado, o objeto), o significado da criação é indutivo, ou seja, ele vai do singular ao universal, que vai desde o trabalho original ao seu significado para todos os homens, na lei ou na razão (idealmente) ${ }^{11}$. A experiência artística é uma aventura livre, mesmo que inclua um tempo de trabalho, a servidão, o consentimento, a obediência à lógica do material (o corpo, os cinco sentidos, a madeira, o mármore, o arame , a voz, o instrumento, o texto, o significado, a verdade). Nietzsche gostou desta frase de Turenne, que se dirigia ao seu corpo: "Você treme, carcaça? Você tremeria muito mais se soubesse onde eu o levo!".

A noção de experiência, portanto, tem um momento passivo e um momento ativo e deve ser esclarecida entre esses dois momentos. Nossa experiência é, antes de tudo, na ordem da recepção, internalização das formas a partir do momento da impressão (o termo da impressão é revelador), da sensação e da percepção. Essa passividade sensivel nunca é, no entanto, apenas passiva: há de fato uma atividade subterrânea de receptividade, que pressupõe estruturas, lógicas, formas já existentes, a priori (inatas) e/ou adquiridas (a posteriori), que possibilita a recepção das impressões possiveis, que acolhem as impressões.

Filosoficamente, há um enigma, e é Aristóteles, empirista e racionalista, quem primeiro ficou atônito com essa afinidade lógica entre a sensibilidade do sentimento e a forma material do sentimento ${ }^{12}$ : como é que existe um sentimento em nós, como a dupla face da sensação, a "correspondência conjunta" entre o sentimento e o sentido, como se o sentimento fizesse uma pergunta à qual o sentido já estava armado para respondê-la, para o qual ele já é sensível? Como é que somos sensíveis a tal matéria, a tal cor, a tal vibração, a tal ritmo, a tal tom de voz, a tal forma? E até, como é que podemos compartilhar essas sensações, que podemos concordar com elas, que existe um "comum sensível", um universal sensível? O que essa "harmonia" sig-

\footnotetext{
11 Lembre-se que Brecht chama seu teatro de o Teatro da Era Científica: teatro indutivo. Cf. A Compra do Cobre e Pequeno Organon para o Teatro.

12 Ver Aristóteles: Da Alma e especialmente Analíticos Posteriores, último capítulo, sobre os princípios do conhecimento.
} 
nifica? A resposta clássica (a de Aristóteles) é: "Natureza”. Outros pensarão em Deus, ou na Vida (e sua evolução). Vamos aprofundar este caminho para dramatizar: para que deveriamos ter as desarmonias do excesso, naquelas experiências violentas que vão além do espectro de nossos sentidos, que saturam nossas sensações, como em deslumbrantes ou ensurdecedoras, onde nossos limiares de percepção de luz e som são pulverizados, mesmo para o nosso espanto - ou como naquelas emoções transbordantes que nos fazem delirar com terror ou entusiasmo? Vemos isso: a metafísica do enigma do mundo começa a partir da sensação. No começo é a emoção.

Este momento passivo de recepção é na verdade já muito ativo, dinâmico, tanto na pré-disposição nervosa (a lógica dos nossos sentidos) - predisposição natural e cultural (histórica), como na disposição - que desta vez é a da alma, a mental, a psíquica, e até da alma singular: é necessário estar pronto. O primeiro dos preparativos é então a formação com a preparação, melhor, a formação com a recepção, sua postura, a sua atitude ${ }^{13}$. Portanto, é necessário ouvir o que Pasteur diz: "O acaso só favorece as mentes preparadas". Imagens da abertura indicam bem: receber, acolher-recolher-colher (o primeiro significado de lego leg-, logos: eu li, e reli - do verbo ler - e acrescento, eu ligo, eu religo - do verbo ligar - ter a mente aberta, receptiva, tolerante, sem inibição ou censura, para fazer bouquets de sensações a fim de capturar tudo o que acontece. E acontece para estarmos atentos a tudo. Como insetos, todas as antenas de fora, como se fôssemos uma presa em potencial para os predadores - estar em guarda.

3.3. Vamos ao centro da idéia: reunir grupos de sensações e percepções é, sem dúvida, a primeira obra do logos, da razão em nós - e não é uma razão pura ideal, mas uma razão material, sensível (é Diderot, seguindo os epicuristas, que coloca a melhor ênfase nessa dimensão imanente da obra da razão, contra a leitura idealista dos racionalistas clássicos - Platão, Descartes, Kant). Mas então, obviamente, o assunto sensível não permanece simplesmente nesse estágio único de receber impressões. Porque a questão é: o que retemos, o que resta, o que resiste em nós dessa realidade? Isto supõe um trabalho da mente, portanto do tempo, da paciência, do esforço, do sofrimento, da adversidade (da matéria, da forma, dos outros espíritos).

De fato, a mente deve operar uma seleção, uma seleção entre as impressões, como uma peneira, uma eclusa de decantação, e essa atividade é chamada de memória (uma memória fisiológica, sensível e nervosa mais que uma memória intelectual). Mas essa memória precisa, no entanto, do trabalho da linguagem e, em particular, do trabalho da denominação (dar um nome). A denominação pode basear-se, por um lado, nos nomes já existentes da língua vernacular ou na língua acadêmica, técnica, cultural ( $a$ arte tem um vocabulário técnico muito preciso), por outro lado, na capacidade de alguns (os gênios ou em qualquer caso, os legisladores da arte) para dar novos nomes ao que é realmente novo ${ }^{14}$. Pequeno jogo coletivo: busquem na tradição teórica do Teatro e do Teatro de Marionetes que conceitos poderiam ser criados para indicar a

\footnotetext{
13 Os pedagogos da moda estão nos martelando com seu "aprender a aprender". Na realidade, é antes um aprendizado para sentir, receber, acolher, intuir, aprender a nomear, aprender a crescer.

${ }^{14}$ Ver Nietzsche, A Gaia Ciência, § 261: "O que é originalidade? Algo que ainda não tem um nome, ainda não pode ser nomeado, embora esteja diante de todos os olhos. Tais são os homens que geralmente são apenas os nomes das coisas que os tornam visíveis".
} 
verdade de tal objeto, de tal ato, de tal processo.

Eu acabei de falar sobre denominação. Proust apontou um fato que é trágico para nós, que sonhamos constantemente com fusão e continuidade, enquanto essa continuidade é impossível: "Sentimo-nos em um mundo, pensamos e nomeamos em outro, podemos, entre os dois, estabelecer uma concordância, mas não preencher a lacuna" (O Lado de Guermantes).

Isto é essencial: como Aristóteles aponta no final de Segundos Analíticos: o nome, a palavra, a noção concilia e retêm, na alma, a lógica e a natureza das sensações - se não, essas sensações giram e seguem no fluxo. Seu nome se torna irresistível e irreversível. O nome torna possível lutar contra o poder dissolvente do tempo, para resistir ao esquecimento da duração psíquica. Na verdade, devemos "segurar", devemos "reter" (ou seja, lembrar, estabilizar, manter, mas também aprender por uma forma de memória). A retenção é feita primeiro pela "denominação", no sentido da nomeação e invocação (no sentido de vocação ou mesmo provocação!).

De fato, toda a questão está presente e surge em nossa mente: o que fazer da irrupção, brutalidade, grosseria, primitividade da sensação de materiais e formas, se não transformar, metamorfosear, sublimar em imagens e signos de fala e expressão material/ espiritual? Resposta: prioridade para formar. Devemos retornar ao que Proust diz: falamos em outro mundo que não o mundo imediato, em particular, quiça privado, de sensação. Nós, portanto, nomeamos em um mundo socializado pela linguagem instituida, que é o nosso banho amniótico espiritual comum. É neste nível de sinais corporais (os sinais de pura práxis: gesto, olhar, endereço) e palavras (substantivos, verbos - signos linguísticos) que acessamos o outro homem e vice-versa.

O teatro é, entre outras artes, a modelagem artística completa (assim como a ópera), desse complexo intersubjetivo, na medida em que a sensação e a impressão imediatas não são suficientes. De fato, se a fronteira entre o olfato e a fala é intransponível, devemos encontrar termos equivalentes, equivalências. Esta é a questão, entre outros, da literatura e do teatro - mas também diz respeito à poesia, dança ou música. A transformação de impressões em signos e formas artísticas é, portanto, uma questão de conversão da energia psíquica através da forma, cuja regra é a equivalência entre valores heterogêneos entre si.

\section{Conclusão}

\section{Eu concluirei com duas idéias.}

A. Primeiro, é necessário defender uma positividade existencial da arte, uma fecundidade da arte. A fertilidade que diz respeito à descoberta e à invenção de si mesmo, ao ganho de poder, à ampliação do campo de consciência e à afirmação de uma individualidade mais forte. O obstáculo a esse processo, mas também à sua chance, é que a existência humana é mista. Primeiro, de necessidade (de determinismos muitas vezes inconscientes - determinismos materiais, sociais, físicos, fisiológicos, nervosos, morais, mentais, passionais, ideológicos e até racionais - o que os filósofos Platão, Leibniz, Spinoza, Kleist, Jünger viram como a noção de "autômato espiritual"15). E,

\footnotetext{
${ }^{15}$ Os filósofos em questão são Platão, Spinoza, Leibniz em particular. Ver Ph. Choulet, A marionete, instrumento óptico da condição humana: 0 autômato espiritu-
} al, As cenas filosóficas da marionete, coletivo sob o dir. H.Beauchamps, F.Garcin-Marrou, J.Nogues e E.Van Haesebroeck, ed. L’Entretemps, 2016. 
segundo, a existência humana é mista de emersão, de explosão, explosão de liberdade: algo acaba sendo um evento, chega de surpresa, explodindo e com "ex-pressão". Esse surgimento é obviamente eminentemente contingente (pode não ser, pode ser algo diferente do esperado ou esperado). Segundo Marguerite Duras (Os Lugares de Marguerite Duras), o processo "criativo" pressupõe uma longa espera passiva, uma atitude de "peneira", e não uma vontade sobrehumana e prometéica, e não uma passagem em vigor. Não somos "nós" que expressamos (este é o mito narcísico da expressão de uma interioridade profunda - enquanto Freud constantemente nos lembra que o nosso eu é superficial), mas é algo que é expresso em nós e por nós. Nosso dever de expressão diz respeito a tudo que não seja nós mesmos: guerra, violência, infelicidade, servidão, ódio, mas também amor, salvação, solidariedade, justiça.

Isso nos ensina muito sobre nossa natureza humana, e especialmente sobre o nosso "eu": uma formação de compromisso (Freud), uma forma de identidade imperfeita, indecisa, ainda não fixa, instável e às vezes muito doente (Nietzsche); uma natureza humana encravada entre duas perfeições, a do animal e seu instinto, e a de Deus e sua onisciência, sua onipotência (o esquema Deus/Animal vem de Kleist, em Sobre Teatro de Marionetes). Isso é para dizer que a nossa liberdade não é absoluta: não há livre-arbítrio, mas tem um jogo de vôo, uma "peteca", como a vertigem do jogo (ilinx) , o jogo de combate (agón/pólemos), a chance de jogo (alea), o jogo mimesis/mímica (imitação/ficção, simulação), e isso a partir do mecanismo associativo de impressões, afetos e pensamentos.

A longa paciência da passividade ativa é o que chamo de arte da utoporosidade, a arte de se tornar autoporoso, penetrável (aprender a escolher, a receber, a se tornar anfitrião, para fazer seu mel de tudo e qualquer coisa). Obviamente, ninguém sabe quando a fruta estará madura e cairá da árvore. Contingência, sempre. Como Aragon disse, "nem todo mundo é Verlaine", muito menos Mozart. Mas cada um tem a sua maneira, cada um tem seu trabalho e sua graça, cada um tem seu modo de realização, sua singularidade. Kant diria: "por falta de uma intuição original como Deus é, devemos nos contentar em ser intuições derivadas". Tudo é uma questão de derivações e escolhas, de preferências quanto a essas derivações. Para cada uma de suas derivações há desvios, portanto. Para cada corpo, seu espírito e seu acervo. É uma "prova pelos efeitos", como dizem os filósofos: o princípio dos indiscerníveis caros a Leibniz (o fato de que existem na natureza apenas diferenças) é um dos motivos profundos do experimento artístico/estético.

Cada um tem a sua perfeição, cada um de seu tipo. Mesmo a arte das crianças, a arte bruta e a arte dos doentes mentais, revelam uma verdade do pequeno "passo à parte", da originalidade, mesmo que modesta. Isto serve para nos fazer sentir, mesmo na nuance, para nos mostrar e nos fazer ouvir o que nunca foi experimentado, visto ou ouvido. Uma forma de domínio, libertação, emancipação, jogo da liberdade está emergindo, uma pequena base para o destino.

Há um anúncio de uma forma de sabedoria e moderação que deve ser lembrado contra as ideologias enfáticas contemporâneas: que ninguém é obrigado a ser revolucionário; não há indignidade em ser apenas bom trabalhador, bom artesão, bom profissional, bom aluno, bom discípulo - saber variar os temas, é excelente. Ser um

${ }^{16}$ Podemos reler com alegria a feroz diatribe contra o gênio lançado por Diderot em O Sobrinho de Rameau. 
gênio absoluto não é a única dignidade criativa ${ }^{16}$.

Nossa modernidade defende, assim, uma verdadeira democracia na arte, ainda que mantenha o eixo vertical da aristocracia dos gênios, dos grandes mestres e dos criadores, como na ideologia da história da arte ou em seu discurso nos museus. Ainda significa que, para nós, modernos, não há progresso na arte. Mas há certamente um nas mentalidades que alimentam ou envenenam as teorias e ideologias da arte ${ }^{17}$. Essa atenção à igualdade na arte está enraizada em uma apologia do inconsciente e em uma crítica ao mito do gênio ou da vontade consciente livre.

B. Também enfatizo a importância da descentralização e desvio na experiência artística/estética. Por quê? O que está em jogo é o elo entre o poder da juventude e a aprendizagem, treinar e dar treinamento. Para Bachelard (A Formação da Mente Científica), a ciência é sempre jovem porque aprende, enquanto nossa consciência ainda é velha com seus preconceitos - tende a repetir formas de crenças ainda não criticadas. A "velhice" do espírito humano é a maligna prega da alma: o lado "rançoso" do sistema de opiniões e convicções, a priori, de preconceitos, de ideias prontas, de idéias recebidas; o lado mofado do desprezo, condescendência, incuriosidade, cautela e medo, pânico da aventura da criação, daquela má repetição da qual o profeta lamentou no Eclesiastes: "nada de novo sob o sol "). Georges Lapassade, em L'entrée en la vie, um ensaio sobre a incompletude do homem, promoveu, a noção de neotenia, que define o poder dos elementos de rejuvenescimento e renovação nos vivos e, especialmente, nos humanos. Como se fosse um processo de cura mental, um efeito de autocuidado, mas uma cura e um cuidado que não só reparam (como a resiliência cara a Boris Cyrulnik), porque inventam novas formas em nós.

Observe o quanto o primitivo, a criança e o artista mentalmente doente são menos sensíveis do que os artistas maduros e fortes de sua "vontade de arte", à inibição imposta pelo superego, a censura implícita do olhar e a sobredeterminação, o julgamento dos "outros". Porque o que está em jogo é a inocência do gesto: todo artista verdadeiramente criativo procura este momento sem história, antes da história, fora da história, onde se liberta de uma herança pesada demais porque se está "pensando" demais ${ }^{18}$ - este momento de graça é o êxtase criativo. É por isso que a criança, o louco, o simplório e o primitivo tornaram-se, no século $\mathrm{XX}$, modelos modestos e justos de produção e totens reais da criação da arte moderna.

Agora, a juventude da alma revela-se em sua coragem de se afastar de si mesma, esquecer-se de si mesma, como numa revolução copernicana invertida: o sujeito humano que se tomou pelo centro do círculo do mundo, pelo "transcendentalismo" (Kant), ao impor suas formas ao objeto, é apagado diante do objeto (que se torna o objeto caro a Francis Ponge). Um objeto que determina os processos de pensamento e gesto do sujeito humano (o termo gestus é de Brecht). O desvio através do objeto traça como que uma elipse, aparece em dois pontos focais, sujeito-objeto: a experiência artística não é nem a contemplação de pinturas inertes e mudas, nem a

\footnotetext{
${ }_{17}$ A ideologia da mimesis tem pesado sobre a verdadeira concepção da arte (Florence Dupont: Aristóteles ou o Vampiro do Teatro Ocidental). Caberá a Nietzsche insistir, ao mesmo tempo, no fato de que a arte não é uma cura para a vida (porque a vida não é uma doença), que a arte é, ao contrário, uma invenção viva para se elevar, uma inteligência maior da vida, uma intensificação da vida e, finalmente, que a mimesis em questão é mais ficção, mentira, máscara, simulação, arte das aparências e ilusões (de modo análogo ao mimetismo dos animais) - invenção de outra vida que não é a imitação da primeira vida, mas a recriação, reinvenção da vida por si mesma. O Colégio de Sociologia (Georges Bataille e Roger Caillois) retoma essa idéia frutifera de arte como uma produção autônoma de ficções e ilusões lúdicas, assim como um lugar de resistência a ilusões escravizadoras e alienantes.

${ }^{18}$ Nietzsche: Assim Falou Zaratustra, Prólogo, "As três metamorfoses", a figura do camelo.
} 
imposição ou a injeção violenta de formas subjetivas em um matéria que seria passiva. Pelo contrário, o objetivo móvel do espírito se move e gira, de sua posição e para a do objeto, para frente e para trás, e constantemente. O círculo narcísico torna-se uma elipse, uma figura de foco duplo (o sujeito humano e o objeto real, mental/imaginário ou simbólico) ${ }^{19}$. É um deslocamento mental, a arte da animação de bonecos como um fantoche inerte, ou a arte de ventríloquos como bons modelos. É por isso que encontrar o Teatro de Marionetes é uma boa escola de modéstia consciente, bons delírios, inibição da imagem de espelho e um bom remédio para a mídia contemporânea: narcisismo patológico individualista.

Uma fórmula de Kant enuncia muito bem este trabalho de efígie através da nocão de endereço, no sentido de dirigir-se a alguém: "pensar, é pensar em si mesmo, colocando-se no lugar de qualquer outro"20 - esta é a segunda máxima do senso comum, a assim chamada máxima do pensamento expandido e compartilhado - e constitui, a nosso ver, uma verdadeira matriz para entender esta jornada de aprendizagem: o acolhimento ( a visão, a audição, a observação) e a invenção (a produção, a criação) das formas, supõem uma capacidade de abandono por parte do sujeito humano, um poder de suspensão do impulso do direito de passagem, da consciência e vontade, que agora é chamado de "deixar ir". Como diz o pianista canadense Glenn Gould: "A moralidade nunca está do lado dos carnívoros".

É isso que a lógica nos diz sobre o que Winnicott chama de objeto transicional ${ }^{21}$, que primeiro cria um amortecedor entre a violência resistente do real e nossa psique. É o caso do cobertor caro a Linus, personagem dos quadrinhos de Charlie Brown, de Schulz. Ou de um bichinho de pelúcia. Estes são brinquedos macios, elaborados no fundo do "peito da mamãe". Ou uma canção de ninar que cantamos para colocar as crianças para dormir. Mas o exemplo clássico é o do jogo do fort- $d a^{22}$ relatado por Freud, onde uma criança pequena inventa o jogo do carretel para controlar a ansiedade da partida da mãe. A necessidade de trabalhar aqui é notável: tal objeto eleito como objeto de amor, fetiche, amuleto, talismã, se interpõe entre certas partes do mundo exterior e certas formas dos nossos desejos, para nos permitir encarar o choque do real, que sempre estourou violentamente em nossa esfera mental (mesmo que tenhamos esquecido e/ou se reprimimos essa violência). É também conhecido como jogo do carretel. Freud, enquanto cuidava do seu neto na ausência da sua filha, observou que o menino não chorou, e que passou a brincar jogando um carretel, preso a um fio, de dentro do berço para fora, de modo que o carretel desaparecia sob a cama. Repetia esse jogo inúmeras vezes. Quando jogava fora conseguia articular um som: ó...ó...ó, e quando puxava o fio e recuperava o carretel dizia: dá...dá...dá com expressão de alegria. Freud intitulou como fort - palavra alemã que significa fora, ir embora e dá que significa aqui, e percebeu que o menino tratava de simbolizar a mãe por meio do brinquedo, expressando sua saída (fort) e a felicidade de seu retorno (dá). Assim, no caso do jogo do carretel, o objeto transicional é também aquele que vai, para nós, à conquista de outro real, em uma função utópica, como em nosso lugar,

\footnotetext{
${ }^{19}$ Este é um tema que especifico no artigo A Marionete na História das Artes, Revue Théâtre aujourd'hui, $n^{\circ} 12$, Les Arts de la Marionnette.

${ }^{20}$ Ver Kant: Crítica da Faculdade de Julgamento, $§ 40$. A primeira máxima é: "pensar por si mesmo" (pensamento autônomo); a terceira é: "pensar de maneira consistente" (pensar com responsabilidade).

${ }^{21}$ Ver Winnicott: Jogo e realidade, Gallimard.

${ }^{22}$ Ver Freud: Ensaios de Psicanálise: Além do Princípio do Prazer, (1920), cap. 2.
} 
como para nós, como em nosso serviço. Desde que eu deixe livre para implantar seus poderes: um personagem de teatro, um texto de papel, uma máscara, uma escultura, um boneco tem uma perfeição limpa, mas às vezes bem escondida, e inventar, que eu devo servir. Cabe a cada um, por sua vez, servir à necessidade interna do outro.

Um pouco mais acima, estávamos falando sobre o enigma do acabamento do trabalho: quando sabemos, além disso, que nosso trabalho está acabado, acabado, perfeito, isto é, "perfeito em sua espécie"? Resposta, quando "sentimos" e quando sabemos que há uma necessidade interior, na relação íntima que mantemos com o nosso produto, através das formas de práxis que presidiram a sua gênese (praxis pura, práxis poética, práxis teórica). "Necessidade interior": esta é a definição que Kandinsky nomeia há um século em, Do Espíritual na Arte, o último critério para o reconhecimento da obra de arte e a existência como uma perfeição ética: segura ou não segura? Está de pé ou não? Não nos esqueçamos de Wittgenstein: "Ética e estética são uma só coisa" (Tratado Lógico-Filosófico). 
Bibliografia indicativa (apenas cito os textos direcionados por minhas observações).

- Sobre as noções de brincar e mimesis/ mimetismo.

Roger Caillois, Jogos e Homens, Gallimard.

D. Winnicott, Jogo e Realidade, Gallimard.

B. Boie, O Homem e seu Simulacro, Ensaio sobre o romantismo alemão, José Corti.

- Sobre o pensamento humano arcaico.

C. Lévi-Strauss, O Pensamento Selvagem, cap. I: A ciência do concreto, Plon.

G. Lapassade, $A$ entrada na vida, um ensaio sobre o homem inacabado, Meia-noite.

- Sobre as artes do homem comum.

M. Thévoz, Art brut, Skira.

J. Dubuffet, O homem comum no trabalho, Gallimard.

H. Prinzhorn, Expressões de Loucura, Gallimard.

- $\quad$ Sobre as Marionetes

Kleist, Sur le théâtre de Marionnettes.

$\mathrm{Ph}$. Choulet, « La Marionnette dans l'histoire des arts », Revue Théâtre aujourd'hui, $\mathrm{n}^{\circ} 12$, « Les Arts de la Marionnette » (bilingue français/anglais).

Les scènes philosophiques de la Marionnette, collectif sous la dir. d'H. Beauchamps, F. Garcin-Marrou, J. Noguès et E. Van Haesebroeck, éd. L'Entretemps, 2016.

A. Gaudin, La Marionnette et son théâtre, Presses Universitaires de Rennes.

Oskar Schlemmer, Théâtre et abstraction, L'Age d'homme.

Colóquio UNIMA, Targoviste, Romania, junho 2017

Este texto traduzido, do francês, por Maria de Fátima Moretti (Sassá), e também se encontra publicado em francês neste número do periódico. Professora -Doutora, do Curso de Teatro - Universidade Federal de Santa Catarina (UFSC).

sassamorettiagmail.com

Recebido em: $12 / 08 / 2018$

Aprovado em: 12/08/2018 